\title{
STRUKTUUR - UITLEG - BOODSKAP 1
}

\author{
L. Floor \\ Departement Nuwe Testament \\ Potchefstroomse Universiteit vir $\mathrm{CHO}$ \\ POTCHEFSTROOM
}

\begin{abstract}
With the publication of a commentary on the Epistle of James an imporient and valuable instrument has become available to biblical scholars and preachers. The purpose of this anticle is to introduce this commentary to the readers. In order to accomplish this purpose, the basic principles on which this commentary is based, are discussed. After a few critical remarks, specifically aimed at the relation between structure and interpretation, the article concludes with an illustration how to gain the optimum value from the practical use of this commentary.
\end{abstract}

\section{INLEIDING}

\subsection{Aktualiteit}

In die jongste tyd is daar in verband met die verklaring van die Bybel besondere klem gelê op verstaansteorieë en taalstruktuur wat in verskillende opsigte 'n verandering in die benadering van die teks teweeggebring het. In die lig van hierdie ontwikkeling het Pretorius (1988a:650-651) die belangrike opmerking gemaak dat daar naas nuwe antwoorde op nuwe vrae ook nuwe antwoorde op ou vrae gesoek is. Maar ons moet volgens Pretorius altyd in gedagte hou dat hoewel dit in sy hoogkonjunktuur nie altyd besef word nie, elke heuristiese metode tog sy beperkings het. ' $n$ Nuwe metode maak nie altyd al die resultate van die ou metode irrelevant nie. Met hierdie behartigenswaardige woorde in gedagte, word gekyk na 'n boek wat beskou kan word as 'n wetenskaplike werk waarby besondere aandag gegee is aan taalstruktuur.

Aan die einde van 1990 het 'n besondere kommentaar op die boekemark verskyn. Hierdie kommentaar dien hom volgens die voorwoord van die redaksie aan as die eerste volume van 'n bepaalde reeks. Die naam van die reeks is Kommentaar op die Nuwe

1'n Bespreking van 'n publikasie van P.P.A. Kotze (Die brief van Jakobus. In: Combrink, HJ.B. red. Kommentaar op die Nuwe Testament. Struktuur - uitleg - boodskap. Kaapstad : Lux Verbi. 1990.) 
Testament: Struktuur - uitleg - boodskap. Met hierdie drieslag word iets van die kenmerke en oogmerke van die reeks aangedui.

Reeds ' $n$ hele aantal jare gelede is beplan om met hierdie reeks te begin. Die inisiatief is geneem deur die Nuwe-Testamentiese Werkgemeenskap van Suid-Afrika van wie se lede hulle verbind het om aan hierdie besondere reeks mee te werk. In samewerking met Lux-Verbi (NG Kerk-Uitgewers) is die eerste deel nou in die handel beskikbaar.

Die oogmerk van die reeks is om in die behoefte van die predikant en die teologiese student te voorsien. By die verklaring van die Bybelboek word erns gemaak met die opbou en struktuur van die geheel en die onderdele van die teks. Dit sluit in - waar ter sake - dat ook aan die narratologiese struktuur aandag gegee kan word.

'n Verdere oogmerk met die reeks is om die uitleg diensbaar te maak aan die prediking. Met die oog hierop word die hoofmomente van die boodskap so aan die orde gestel dat dit moontlik word om die lyne deur te trek met die oog op die prediking in ons eie tyd en situasie. Hiermee is die titel van die reeks verklaar: dit gaan om die struktuur van die teks, die uitleg en sy boodskap.

Professor P.P.A. Kotzé open hierdie reeks. Sy kommentaar is getitel "Die brief van Jakobus". 'n Woord van hartlike gelukwense aan die skrywer mag nie ontbreek nie. Sy kommentaar getuig van harde werk en indringende analise en ook van ryp insig in die Bybelse boodskap oor die algemeen en dié van Jakobus in die besonder.

Wie hierdie kommentaar oopmaak, sal ontdek dat daar in hierdie boek iets is wat afskrik en iets wat aantrek. Wanneer die leser al die struktuuranalises sien, die stilistiese ontledings opmerk en die grafieke bestudeer, mag dit hom miskien daarvan weerhou om die boek te gaan bestudeer. Dit sou jammer wees, want as hy tog by die boodskap kan uitkom, dan sal hy wanneer hy 'n predikant is, ontdek dat hy nou met Jakobus na die kansel kan gaan.

\section{Doelstelling}

Die doel van hierdie artikel is om in 'n uitgebreide boekbespreking die verskyning van hierdie kommentaar (Kotze, 1991) bekend te stel. Daarby word nie in die eerste plek beoog om die teologiese gehalte van die boek aan ' $n$ kritiese beoordeling te onderwerp 
om vas te stel of hierdie kommentaar aan al die vereistes van 'n moderne wetenskaplike kommentaar voldoen nie. Wat die vereiste vir 'n wetenskaplike kommentaar betref, kan dadelik gesê word dat die skrywer die toets volledig slaag: hy het goeie wetenskaplike werk gelewer. Die vraag wat by die bespreking van hierdie kommentaar beantwoord moet word, is of die metode van teksanalise wat in die kommentaar aangewend is, ' $n$ wesenlike bydrae lewer tot 'n beter verstaan van die teks en die brief van Jakobus wat van kommentaar voorsien word.

\section{LTTERATUURVERWERKING}

\subsection{Groot belangstelling vir Jakobus}

Om hierdie kommentaar te beoordeel is dit ook wenslik om dit te vergelyk met andere kommentare wat reeds verskyn het. Daar is egter so oorstelpend baie literatuur oor die brief van Jakobus dat ' $n$ mens nie weet waar om te begin en waar om te eindig nie. Mussner (1967:xii-xiii) gee in die inleiding op sy kommentaar hieroor heelwat inligting, hoewel selfs hy nie alles noem wat in die loop van die eeue oor Jakobus geskryf is nie. Dan is daar ' $n$ magdom artikels oor bepaalde onderwerpe met betrekking tot die Jakobusbrief wat veral in die laaste tyd verskyn het. Dat 'n mens wat eenmaal deur Jakobus aangegryp is, nie maklik van hom loskom nie, het Adamson vir ons gewys: eers het hy 'n doktorale proefskrif oor Jakobus geskryf (1954); daarna het hy in The New London Commentary-reeks 'n kommentaar op Jakobus die lig laat sien (1976). Vervolgens het hy ' $n$ teologie van Jakobus op die mark gebring (1989) om te wys dat die versadigingspunt ten opsigte van hierdie brief nog nie bereik is nie.

\section{Die voor- en nadeel van min literatuurverwerking}

Kotze (1990:212-216) gee hoegenaamd geen aandag aan wat in die loop van die eeue oor Jakobus geskryf is nie: hy gaan in sy literatuurlys nie verder terug as 1916 nie. Hy beperk hom eintlik net tot wat in die laaste drie decennia verskyn het. Verhoudingsgewys het die outeur min literatuur in sy kommentaar verwerk. Ons mag dit egter nie teen hom laat tel nie, omdat die skrywer - en dit is die voordeel - met sy kommentaar die bewys lewer dat hy oorspronklike werk verrig het. Tog moet hier op een leemte gewys word. Vir een kommentaar wat ontbreek, moet ons 'n uitsondering maak. Byna drie jaar gelede (1988) het in die sogenaamde Swart Reeks die uitnemende kommentaar van professor E.A.C. Pretorius op die brief van Jakobus verskyn. Pretorius (1988b) het op 'n totaal ander manier sy kommentaar geskryf. Hy beskou die brief van 
Jakobus as wysheidsliteratuur en toon dan aan hoe die wysheid gevaarpunte in die lewenspraktyk van die eerste lesers ontmasker, gevaarpunte wat die verlossing in die gedrang bring. Pretorius identifiseer nie minder nie as veertien gevaarpunte wat in die brief van Jakobus genoem word. By elke gevaarpunt word dan sowel die negatiewe as die positiewe aangedui. In sy Inleiding (1988b:20) verwys Pretorius, sonder om die naam van die outeur te noem, na die kommentaar van Kotzé wat in voorbereiding is. Daarom is dit enigsins vreemd en onverklaarbaar dat Kotzé in sy kommentaar nêrens na Pretorius se boek verwys nie.

\section{STRUKTUUR}

\subsection{Pretorius en Kotzé se kommentare}

Dit is beslis die moeite werd om juis hierdie twee kommentare wat in die SuidAfrikaanse taalgebied verskyn het en wat tot 'n groot mate dieselfde teikengebied het, met mekaar te vergelyk. Pretorius het in sy kommentaar wel rekening gehou met gesigspunte van onder andere die metode van diskoersanalise en ook die linguistiese metode van Skrifverklaring, maar hy het tog die klem laat val op 'n poging om 'n tematiese en teologiese verband tussen die onderdele van die brief van Jakobus te vind (Pretorius, 1988b:20). Kotzé het op sy beurt in sy kommentaar alle aandag gegee aan struktuurontleding met 'n besondere toespitsing op die perikoopsamehang. Subkolons en kommas is fyn onderskei. Soms is gebruik gemaak van lyne om semantiese en ander verbande aan te dui. Tegelyk het die skrywer uitvoerig ingegaan op die styl van Jakobus waarby sinsbou en retoriek breedvoerig bespreek is. Die doel van sy ondersoek was om te konsentreer op die ontleding van die teks. Wanneer ons die perikoopindeling van die twee kommentare met mekaar vergelyk, vind ons uit dat daar basies geen verskil is nie. Kotze (1990:30-41) kom na ' $n$ redelik ingewikkelde beredenering (waarin hy veral aandag gee aan die verbinding tusssen die verskillende perikope) tot prakties dieselfde konklusie as Pretorius (1988b:23-26) wat op 'n betreklik eenvoudige manier ' $n$ aantal gevaarpunte in die brief van Jakobus identifiseer (1988b:21,23-26).

\subsection{Struktuurbepalende merkers}

By sy beredenering maak Kotzé gebruik van wat hy struktuurbepalende merkers noem (1990:31). Hy noem aan die begin van sy kommentaar reeds 'n groot aantal struktuurmerkers (1990:12-15). Dit is jammer dat hy nie 'n duidelike definisie aanbied van wat 
'n struktuurmerker presies is nie. Uit sy inleiding oor struktuurmerkers kry 'n mens die indruk dat 'n woord as 'n struktuurmerker beskou kan word as dit semanties-verwant is. Dit sou beteken dat ons struktuurmerkers op die semantiese vlak moet soek. Kotzé (1990:12) gee 'n hele aantal struktuurmerkers en dan ook net die belangrikste. Hy het die struktuurmerkers in 'n afsonderlike rubriek geplaas met 'n aanduiding van die verspreiding (Kotzé, 1990:12-15). Sy oorsig toon aan dat dit vir hom net gaan om werkwoorde, selfstandige naamwoorde en byvoeglike nalamwoorde. Is dit uit die oogpunt van die algemene taalwetenskap aanvaarbaar? Daar is na my wete net twee persone wat vir sover dit die Suid-Afrikaanse taalgebied betref, 'n poging onderneem het om te omskryf wat 'n struktuurmerker is. Du Plessis (1989:5) dui struktuurmerkers aan as "terme of woordgroepe wat bepaalde sake merk of aanstip wat vir die verstaan noodsaaklik is". Hy maak onderskeid tussen struktuurmerkers en struktuurdraers. Struktuurdraers is identies of semanties-identies aan struktuurmerkers en bou die saak wat in struktuurmerkers gestel word, verder uit (1989:5). Coetzee (1988:23) gee as definisie: "Met 'struktuurmerkers' word bedoel enige teken, duiding, semeion, wat die skrywer eksplisiet of implisiet, doelbewus of onbewus [oor die doelbewustheid al dan nie kan die leser moeilik oordeel] in sy teks ingebou het om dit effektief met die ontvanger te laat kommunikeer". In die Greek-English Lexicon van Louw en Nida vind ons twee aparte semantiese velde (89 en 91) wat as merkers aangedui kan word. Merkers is woorde (gewoonlik voorsetsels en partikels) wat in die eerste plek_die funksie vervul om die verhouding tussen 'inhoudswoorde' en frases te merk (Botha, 1989:8). Louw en Nida gebruik in hulle woordeboek die term discourse markers (1988:811). Kotzé gaan baie verder en kom met so 'n groot aantal struktuurmerkers dat die indruk geskep word dat amper alle woorde struktuurmerkers is. Op die ou end is daar dan geen enkele woord meer wat nog as 'n struktuurmerker aangedui kan word nie. Om die verwarring nog te verhoog, voer die skrywer later die term sleutelbegrip in (1990:131). Hier moet aan die skrywer van die kommentaar gevra word of hy met sleutelbegrip dieselfde bedoel as struktuurmerker. Die verwarring is veroorsaak deur die feit dat die skrywer van die kommentaar nie duidelik aangegee het wat hy presies met 'n struktuurmerker bedoel nie. Soms heg Kotzé te veel waarde aan 'n bepaalde struktuur. Ons sien dit wanneer hy by die knap struktuurontleding van Jakobus 2:18 die stelling maak dat Jakobus met die struktuur van die Skrifbewys die integrale eenheid tussen geloof en werke wil aantoon (1990:131). Ons moet aanvaar dat Jakobus met die Skrifbewys self, en nie noodwendig met die struktuur van die Skrifbewys nie, wil aantoon hoe nou geloof en werke met mekaar verbind is. 


\section{Die oorhoofse struktuur}

Besonder waardevol is Kotze se bydrae met betrekking tot die beskrywing van die oorhoofse struktuur van die brief. By die vasstelling van die oorhoofse struktuur van die brief maak Kotze gebruik van die klimaktiese ontwikkeling van temas by Jakobus (1990:31). As temas word dan genoem: wysheid, gebed, die verhouding tussen arm en ryk, die spreke van die mens. Maar behalwe 'n klimaktiese strukturering deur middel van skerp kontraste, is daar volgens Kotzé 'n verdeling in twee hoofdele waarvan die eerste deel (1:2-2:26) sterk bevestigend is en die tweede hoofdeel (3:1-5:20) sterk konfronterend is (1990:31). Die skrywer sluit hom hier aan by die ondersoek van 'n werkgroep oor die gebruik van die Ou Testament in die brief van Jakobus te Tübingen (1977) en Chatenay-Malabry (1978). Volgens hierdie ondersoeke sou die afleiding gemaak kon word dat daar in elk van die twee afdelings van die brief 'n preek oor 'n Ou-Testamentiese teks opgeneem is: die eerste afdeling sou dan 'n preek wees oor die naasteliefde na aanleiding van Levitikus 19:18 en die tweede afdeling 'n preek oor bekering na aanleiding van Spreuke 3:34. Die afleiding wat gemaak is, is hipoteties. Met sekerheid kan niks vasgestel word nie. Wel moet dit waarskynlik geag word dat die brief van Jakobus opgebou is uit preekstof, miskien preke of toesprake wat Jakobus in Jerusalem gelewer het (Greijdanus, 1949:278), maar of daar sprake was van teksprediking en wat die tekste presies was, is moeilik om vas te stel.

\section{$3.4 \quad$ Struktuurooreenkomste}

Die skrywer van die kommentaar het 'n treffende strukturele ooreenkoms tussen Jakobus 2:1-13, 2:14-26 en 5:7-11 ontdek. Hy vind die volgende elemente in daardie drie perikope:

$\begin{array}{llll}\text { Tema } & 2: 1 & 2: 14 & 5: 7 \\ \text { Voorbeeld } & 2: 2 & 2: 15 & 5: 7 \mathrm{~b} \\ \text { Konklusie } & 2: 4 & 2: 17 & 5: 8 \\ \text { Argument } & 2: 5-7 \mathrm{a} & 2: 18-19 & 5: 9 \\ \text { Skrifbewys } & 2: 8-11 \mathrm{a} & 2: 21-15 & 5: 11 \mathrm{a} \\ \text { Konklusie } & 2: 12-13 & 2: 21-25 & 5: 11 \mathrm{~b}\end{array}$

In die lig van hierdie struktuurooreenkomste kan met reg gevra word of ons hier nie met 'n bepaalde preekmodel van die vroeë kerk te doen het nie (Kotzé, 1990:194). Uit homiletiese gesigspunt is hierdie struktuuranalise baie belangrik. Die brief gee hiermee ' $n$ aanduiding op watter manier daar in die vroeë kerk gepreek is. Pretorius 
(1988b:16) het op grond van Jakobus se gebruik van die diatribe-styl geoordeel dat in die skrywe van Jakobus 'preekstof' in die vorm van 'n brief aangebied word.

\subsection{Die proses van struktuurontleding by Kotzé}

In die proses van struktuurontleding gebruik Kotzé twee struktuuraanduidings. Hy maak gebruik van die terme makrostruktuur en oorhoofse struktuur. Met makrostruktuur bedoel hy die samehangende struktuur van die brief (Kotzé:1990:30), terwyl die oorhoofse struktuur die ooreenstemmende begin en einde van die brief aandui (Kotzé,1990:31). Wanneer ons die proses van struktuurontleding volg soos Kotzé dit in sy kommentaar gedoen het, dan blyk dit dat die skrywer met hierdie ontledingsprosedure volkome op semantiese vlak beweeg. Eers bied Kotzé in sy kommentaar vir ons die makrostruktuur van die brief (1990:30-41) waarin hy baie aandag gee aan die oorhoofse struktuur van die brief. Hy wys dan op die struktuur van die ringkomposisie of inclusio wat blyk uit die ooreenstemmende begin en einde van die brief. Die klimaktiese ontwikkeling van die temas kry volle aandag waarby ook, soos reeds aangetoon, die tweedeling van die brief as twee afsonderlike preke oor twee verskillende tekste ter sprake gebring word. Op ' $n$ indringende wyse word in hierdie afdeling ook die perikoopverbindings ontleed (1990:33-41). Die beredenering is uiters sorgvuldig en getuig van deeglike studie. Kotzé is telkens op soek na die betekeniseenheid om daarmee 'n perikoop te kan afbaken. In vergelyking met Pretorius (1988b) gee Kotzé baie meer aandag aan die verskillende perikoopverbindings. Vir die formulering van die perikoopinhoude het Kotzé probeer om al die struktuurmerkers wat 'n sleutelfunksie vir die inhoud van 'n bepaalde perikoop vervul, te verantwoord (1990:35-41).

Nadat Kotzé die perikoopinhoude sorgvuldig geformuleer het, het hy die inhoud met mekaar vergelyk en tot die konklusie gekom dat die perikope relatiewe selfstandige betekeniseenhede vorm binne 'n oorhoofse strukturering.

\subsection{Die metode van diskoers-analise}

By die struktuurontleding van die verskillende onderdele van die brief maak Kotzé gebruik van die metode van diskoers-analise. By elke perikoop word eers die struktuur ontleed, daarna word kommentaar op die betrokke perikoop gelewer en ten slotte word die boodskap wat in die perikoop opgesluit lê, opgesom. Hierdie metode om met 
behulp van struktuurontleding via die kommentaar by die boodskap uit te kom, is werklik baie doeltreffend. Die perikoopstruktuur word duidelik uiteengesit en die struktuur van die kolongroepe kry deeglike aandag. Waar nodig, gee Kotzé in sy kommentaar 'n woordgroepering volgens die drie semantiese woordsoorte om 'n teks beter van kommentaar te kan voorsien (1990:65).

Wie Kotzé op hierdie pad volg, kom wel telkens met die vraag watter diens die struktuurontleding bied tot beter verstaan van die boodskap. Daar is soms pragtige voorbeelde hoedat struktuurontleding help om 'n teks beter te verstaan soos later nog aangetoon sal word.

\subsection{Stilistiese analise}

Kotzé het in sy kommentaar ook besonder baie aandag bestee aan die stilistiese analise van die Jakobusbrief. Die brief is volgens Kotze (1990:55) in besonder goeie Grieks geskryf en word gekenmerk deur 'n groot opeenhoping van stylfigure. Taalvaardigheid in styl en ritme kom dwarsdeur die brief voor en Kotzé gee hiervan 'n duidelike oorsig (1990:55-60). Ook toon Kotzé duidelik aan dat agter die Griekse taalkleed van die Jakobusbrief 'n Joodsdenkende skrywer skuil (1990:61-63). By die bespreking van die verskillende kolonstrukture gee Kotze telkens aandag aan retoriese en stylfigure. Hoewel dit baie interessant is, moet die vraag tog gevra word of al hierdie ontledings 'n wesenlike bydrae lewer tot die beter verstaan van die brief. Wanneer ons in die kommentaar by die uitleg van die brief kom, dan verskil die eksegese nie veel van die tradisionele verklaring van die teks soos ons dit in ander kommentare vind nie. Dit is nie negatief bedoel nie, omdat Kotze in sy kommentaar wel deeglik met 'n eie aanpak kom soos later nog aangedui sal word. Die vraag is net of al die kombuiswerk, wat werklik indrukwekkend is, in die kommentaar opgeneem moes word. Uit 'n taalkundige oogpunt gesien sekerlik, maar wat help dit die predikant wat uit Jakobus wil preek of die Bybelstudent wat hom in die inhoud van die brief wil verdiep?

\section{8 'n Grafiese uiteensetting}

Eers identifiseer Kotze (1990:20-29) verskillende herhalingspatrone in die brief van Jakobus wat hy as temas in die brief uitlig. Daarna kom hy (1990:89) tot 'n grafiese uiteensetting van die brief onder die oorhoofse tema seën van beproewing met die oog op die gawes van God. In hierdie verband wys hy op struktuurmerkers wat in aanmer- 
king kom: (1) volmaakte geskenk, (2) seën, (3) volharding, (4) sonde en (5) woord van die waarheid. Dit is nie duidelik hoekom Kotzé juis hierdie vyf struktuurmerkers uitgesonder het nie. Met eweveel reg kan beweer word dat geloof en gebed die eintlike struktuurmerkers van die brief van Jakobus is. Die twee begrippe gebed en geloof loop soos goue drade deur die Jakobusbrief (1:6-8; 5:15-17). Sophie Laws (1980:27) wys in verband hiermee op: "... this characteristic assosiation of faith and prayer" in die brief van Jakobus. Dan vervolg sy met die opmerking: "Faith is that attitude to God which is expressed in prayer, but is also necessary issuing in action". Kotze motiveer vervolgens sy grafiese voorstelling met die konklusie dat perikoop 4 (Jak. 1:12-18) van beslissende betekenis vir die hele brief is. Hierdie perikoop vorm 'n knooppunt vir die ontvouing van die skrywer se gedagtes, en die res van die brief vloei op die een of ander wyse voort uit hierdie perikoop, terwyl belangrike oorkoepelende motiewe in hierdie perikoop ter sprake kom (1990:87). Kotzé se oortuiging dat perikoop 4 (Jak. 1:12-18) van beslissende betekenis is vir die verstaan van die hele brief kan van harte onderskryf word, maar dan is dit wel belangrik vanuit watter gesigshoek ons hierdie perikoop benader. Uit Kotzé se grafiese voorstelling (1990:89) kom aan die lig dat hy die seën van beproewing met die oog op die gawes van God as vertrekpunt geneem het. Hoewel sy indeling op die oog af werklik beïndruk, moet dit tog betwyfel word of die hele brief vanuit die gesigshoek van die seën van beproewing met die oog op die gawe van God gesien moet word. Hier is te veel antroposentries, te veel vanuit die mens na die perikoop gekyk. Lé dit vanweë die teologiese aard van die brief waarop in die volgende paragraaf gewys sal word nie meer voor die hand om die vertrekpunt by God te neem nie? Dit gaan vir Jakobus om God, en in verband daarmee om die egte en suiwere godsdiens voor God die Vader (1:27). In so 'n godsdiens is die kultiese alleen nie voldoende nie; die sosiale is ewe belangrik. In die verhouding tot God speel die sosiale net so 'n belangrike rol as die kultiese (Floor, 1991:107-108).

\section{DIE TEOLOGIESE AARD VAN DIE BRIEF VAN JAKOBUS}

Die brief van Jakobus het ' $n$ baie sterk teologiese aard. Die hele brief van Jakobus "ist ein theozentrisches Dokument" (Popkes, 1986:49). Frankemölle (1990:191) beskou die korrelasie tussen antropologie en teologie selfs as die groot en samevattende tema van hierdie brief. God se wese en sy handelinge is volgens Frankemölle die groot en samevattende tema van die brief van Jakobus. Wanneer die mens in die brief van Jakobus ter sprake kom dan is dit altyd vanuit God gesien. In hierdie verband praat Frankemölle selfs van "die theologische Anthropologie des Jakobusbriefes" (1985:160178). Mussner (1967:97-98) het in 'n ekskurs "Das Gottesbild des Briefes" ook aan die 
teologiese uitgangspunt van die Jakobus-brief aandag gegee sonder om dit egter verder uit te werk. Dit is inderdaad so dat Jakobus sowel aan die begin as aan die einde van sy brief sterk nadruk lê op wat God is en wat hy doen. Aan die begin van sy brief (1:518) wys Jakobus op die volgende:

God as die Gewer van wysheid

God as die Gewer van die kroon van die lewe

God as die Gewer van elke gawe wat goed is

God as die Vader van die ligte

God as die Onveranderlike

God as die Gewer van die lewe

Aan die einde van die brief (1:12-5:11) wys Jakobus weer op God:

God as Wetgewer en Regter

God wat ons lewensloop bepaal

God as die Here die Almagtige

God wat ryk is aan barmhartigheid en ontferming

Kotzé wys in sy struktuuranalise wel op God as die bron van die lewe (1990:89), maar dit staan volgens hom nie in die sentrum van die brief nie. Sy grafiese voorstelling wys dit duidelik uit. Tog wil dit voorkom of ons God as die bron van die lewe hier as vertrekpunt moet neem om die brief reg te verstaan. Ons kan ons die struktuur van die brief soos volg voorstel: 


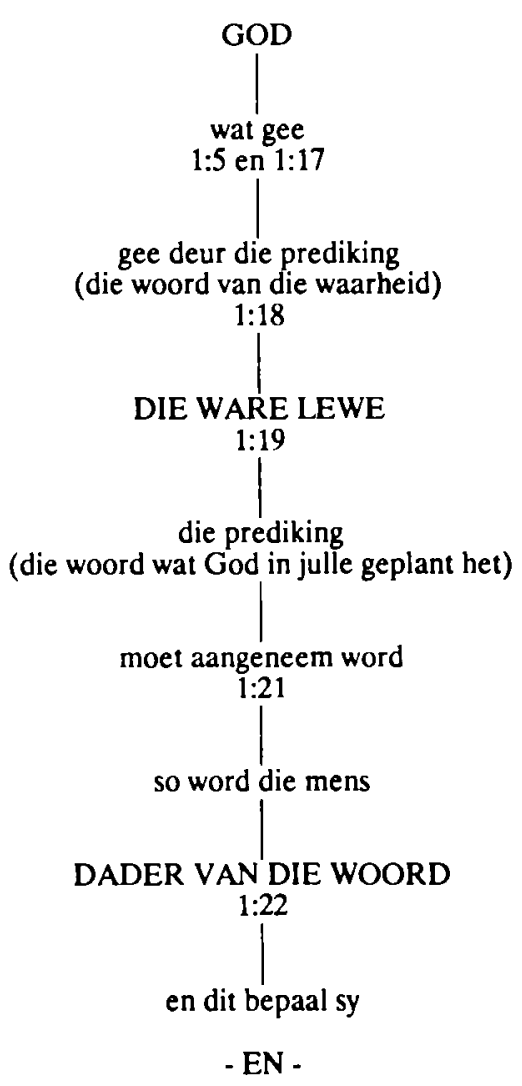

SPREEK

DOEN

1:17-21

$1: 22-25$

$1: 26$

SPREEK EN DOEN

2:12

SPREEK

EN

DOEN

2:1-13

2:14-26

$3: 1-12$

3:13-18

4:11-16

4:1-10

5:7-12

$5: 1-6$

5:13-20 
Die geloof dat God een is, word deur Jakobus bely (2:19). Die lesers word in die brief voortdurend met God gekonfronteer (2:13; 3:11; 4:4-10; 4:12). De Vries (1991:87$88,161-163$ ) toon in sy proefskrif aan dat Jakobus sy lesers daarop wou wys dat hulle vanuit God en wat God is en doen sy brief moes lees. In sy grafiese voorstelling (1990:89) moes Kotzé na my oordeel reeds die teologiese aard van die brief vanuit sy struktuur-analise sterker beklemtoon het.

Daar moet gewaak word om die brief van Jakobus nie eensydig op die dade van mense te betrek asof die spreke nie belangrik sou wees nie. Dit is nie sonder rede dat die skrywer soveel aandag aan die tong gee nie, maar daardie instrument moet geheilig word. Vroom woorde alleen is met betrekking tot die ware godsdiens nie voldoende nie - die daad moet by die woord gevoeg word. Mond en hand moet in die diens van God opgeneem word. Jakobus het 'n bepaalde spreke en 'n bepaalde handeling op die oog en daarom neem 2:12 in ooreenstemming met 1:18'n sentrale plek in die brief van Jakobus in. Ons spreke en handelinge moet altyd op God gerig wees.

\section{RETORIEK IN DIE BRIEF VAN JAKOBUS}

Kotzé gee ook baie aandag aan retoriek in die brief van Jakobus (1990:57-60). Dat hierdie brief ryk aan retoriek is, hoef nie betwyfel te word nie (De Vries, 1991:33-44). Daar is ' $n$ retoriese klankrykheid in hierdie brief wat werklik indrukwekkend is. Kotze gee 'n goeie oorsig van die kunstige stylvolheid van die brief van Jakobus, maar die vraag bly of hierdie stilistiese ontleding 'n bydrae kan lewer tot die beter verstaan van die brief van Jakobus.

\subsection{Die parenetiese aard van die brief van Jakobus}

In die inleiding van sy kommentaar wys Kotze (1990:9-11) op die paranetiese aard van die brief van Jakobus met besondere verwysing na die Hellenistiese paranese. Daar is volgens hom geen twyfel oor die paranetiese aard van die brief nie. Kotzé ontken dat die brief van Jakobus uitsluitend die aard van die Hellenistiese paranese vertoon (1990:10): die wesenstrekke van die tipies Hellenistiese paranese is nie so maklik by Jakobus terug te vind nie. Kotzé werk hierdie stelling van Mussner (1967) en Davids (1982) nie verder uit nie maar daar moet inderdaad onderskeid gemaak word tussen 
die Hellenistiese paranese en die Joods-sinagogale paranese. Jakobus sluit eerder aan by die paranese van die sinagoge.

Jakobus maak veelvuldig gebruik maak van stylfigure wat ons ook vind in die Hellenistiese geskrifte. Die brief van Jakobus is geskryf in die diatribe-styl, maar kan Jakobus se redevoeringstyl op grond hiervan as 'Hellenistiese' diatribe omskryf word? Dit moet selfs ernstig betwyfel word of die styl van Jakobus alleen verwantskap met die Hellenistiese diatribe vertoon. In die eerste plek is die styl van die Hellenistiese diatribe oor die algemeen besonder platvloers. By die Grieke was die diatribe-styl bedoel om die laglus op te wek, en oor die algemeen was die diatribe in 'n triviale vorm gegiet. By Jakobus daarenteen is in sy redevoeringstyl ' $n$ groot erns te bespeur. In die tweede plek kan ons die styl wat Jakobus gebruik, terugvind in die OuTestamentiese geskrifte. Ten derde herinner die styl wat Jakobus gebruik aan die redevoeringstyl van die sinagoge (Adamson, 1954). Predikers in die Christelike kerk het later ook van hierdie styl gebruik gemaak soos blyk uit 'n preek van Chrysostomos (Homilia in Joh 3:3; vgl. De Vries, 1991:20). Die stylvorm wat Jakobus gebruik, kan selfs daarop dui dat hy in sy brief 'preekstof' aanbied.

\section{Die Sitz im Leben van die Jakobusbrief}

Met betrekking tot die Sitz im Leben van die Jakobusbrief kom Kotze (1990:6) met die baie belangrike stelling dat daar niks in die brief van Jakobus is wat nie kan inpas in ' $n$ situasie soos in die eerste deel van Handelinge weergegee word nie. Hier is Kotze se stelling in ooreenstemming met Van Bruggen wat die opvatting huldig dat Jakobus skryf aan Joodse Christene soos ons hulle ontmoet in Handelinge 2-9 (Van Bruggen, 1984:87-88). Moderne navorsers (Perdue,1981:241-256; Vorster,1987:141-142) waarsku dat ons in die brief van Jakobus nie moet probeer om vanuit die teks die sosiale omstandighede van die eerste lesers te rekonstrueer nie; die aard en veral die literêre aard van die brief laat dit nie toe nie. Die brief is immers'n paranetiese geskrif in die vorm van 'n brief. Op grond van die semantiese funksie van vermanings in paranetiese tekste en die feit dat vermanings dikwels tradisionele etiese oorlewerings is wat op verskillende situasies gerig kan word, is dit nie relevant om te gaan soek na 'n konkrete situasie waarna elke afdeling van die teks sou verwys nie. Kotze wys hierdie opvatting af dat die brief nie ' $n$ bepaalde situasie in die oog het nie. Hy maak die belangrike opmerking: "Weliswaar is die meeste aanduidings in die brief met betrekking tot tyd en situasie van so 'n aard dat geenén daarvan afsonderlik geneem, uitsluitsel hieroor gee nie" (1990:10). Hy gebruik dan die pragtige beeld: "Gesamentlik is dit egter soveel strooitjies in die wind wat in dieselfde rigting wys dat die oortuiging posvat dat 
'n bepaalde situasie (en dus ook 'n bepaalde tyd) in die kerk aangespreek word" (1990:10). Wat die tyd betref, ag Kotzé dit moontlik dat die brief reeds voor die val van Jerusalem geskryf is (1990:6). Jakobus skryf oor die rykes wat as onderdrukkers van die armes aangedui word. Die rykes was gegoede grondbesitters en hulle het na die beleg van Jerusalem feitlik opgehou om te bestaan in die omgewing van Judea. Voor die val van Jerusalem was dit egter een van die mees aktuele euwels dat die rykes die armes uitgebuit het terwille van ' $n$ weelderige lewe (1990:6). Kotze dateer die brief van Jakobus binne die periode van 40-62 $\mathrm{nC}$. Met die ontleding van die teks het die oortuiging egter gaandeweg by hom posgevat dat die brief heel vroeg, so vroeg soos 42 $\mathrm{nC}$, gedateer moet word (1990:1). 'n Sterk argument vir'n vroeë datering van die brief van Jakobus is ongetwydeld die aanhalings wat Jakobus maak uit die bergprediking van Jesus (Van der Walt, 1984:34). Nêrens word in die brief van Jakobus die tekste uit die bergrede soos Matteus dit aan ons oorgelewer het letterlik aangehaal nie, terwyl Jakobus die Griekse teks van die Ou Testament baie nougeset aanhaal. Dit mag daarop dui dat Jakobus uit die mondelinge tradisiestof aanhaal. Die ooreenkoms tussen Jakobus se woorde en dié van Jesus is nie volgens die letter nie maar inhoudelik van aard. Die woorde van Jesus word volgens Ross (1972:17) spontaan en met begrip weergegee en het die kenmerk van 'n selfstandige getuienis van die prediking en onderwys van Christus. Jakobus het in 'n gemeenskap gelewe waar die prediking van Jesus in die mondelinge oorlewering 'n gesagvolle rol gespeel het (Kittel, 1942:93-94).

Ten slotte moet aan die einde van hierdie afdeling nog opgemerk word dat die skrywer nêrens in sy kommentaar die bewys lewer dat hy gebruik gemaak het van die woordeboek van J.P. Louw en E.A. Nida nie. Die brief van Jakobus met sy groot rykdom aan woorde leen hom besonder om die beginsel van kontrastering van verskillende woorde binne die betrokke semantiese velde as 'n doeltreffende metode vir Skrifverklaring te toets, maar van 'n optimale benutting of selfs 'n onderbenutting van hierdie woordeboek in die kommentaar is daar nie 'n enkele spoor nie. Dit mag egter wees dat Kotze sy manuskrip reeds so vroeg soos 1988 by die redaksie ingehandig het en dan is hy van alle blaam onthef.

\section{UITLEG}

\subsection{Kommentaar op die teks}

In die tweede deel van elke perikoop-bespreking bied Kotzé sy kommentaar op die teks, die uitleg. Soms is daar reeds verklaring gedoen by die ontleding van die 
perikoop- en kolonstruktuur (1990:75). Om herhaling te vermy, word daar dan nie weer daarna verwys nie. In die kommentaar op die afsonderlike perikope, kolons en tekste is daar heelwat grammatikale verwysings (1990:75, ens.) wat 'n aanduiding is dat die skrywer in sy struktuurontleding net op semantiese vlak gewerk het. 'n Grammatikale ontleding kom dan onder die kommentaar-afdeling. Die vraag is of struktuurontleding in hierdie kommentaar altyd werklik diens lewer aan die uitleg van die teks. Om die vraag te beantwoord, kan ons kyk na tekste uit die brief van Jakobus wat in die loop van die geskiedenis van die eksegese van Jakobus as besonder moeilik en amper as onverklaarbaar beskou is. Ons moet ons beperk tot twee sleuteltekste uit die brief van Jakobus.

\subsection{Die verklaring van twee sleuteltekste}

\subsubsection{Jakobus 2:1}

Hierdie teks word beskou as een van die twee belangrike tekste ten opsigte van die Christologie van die brief van Jakobus. Ook met betrekking tot die Christelike aard var die brief is hierdie teks belangrik. Tot op hede is daar na my oordeel nog geen werklik bevredigende verklaring van hierdie vers gegee nie. Die teks bevat 'n belangrike betiteling van Jesus. Hy word die Here van die heerlikheid genoem. Die teks staan aan die begin van 'n hoofstuk wat handel oor die geloof. In die eerste deel van die hoofstuk wys Jakobus op geloof sonder aansien van die persoon (2:1-13) en in die tweede deel van die hoofstuk (2:14-26) handel hy oor geloof met goeie werke. Die probleem waarmee die leser in Jakobus 2:1 gekonfronteer word, is die volgende: is die teks geskryf in 'n verbodsvorm ('n negatiewe imperatief) of is hier sprake van 'n (negatiewe) indikatief? Pretorius (1988a:652-655) het hom diepgaande met hierdie problematiek besig gehou, en hy kom tot die slotsom dat hier sprake is van 'n drakragtige indikatief en daarom stel hy die volgende vertaling voor: 'My broers, julle besit tog nie op grond van ' $n$ uiterlike beslissing (oor julle) die geloof in ons Here Jesus Christus, die Here van die heerlikheid nie?' Hy motiveer sy standpunt met die verband wat daar is tussen 2:1 en 2:5. Kotzé (1990:120) skryf in sy kommentaar dat die begin van 2:1 op drie verskillende maniere gelees kan word: as indikatief, as inleiding op 'n retoriese vraag of as imperatief. Hoewel hy die eerste twee moontlikhede as aantreklik beskou, kies hy vir die derde opsie met as motivering dat die volgende kolon uitgaan van die lesers as beoordelaars. Struktuurontleding van hierdie gedeelte bied nie 'n oplossing nie. Kotzé (1990:39-40) sien eintlik nie 'n verbinding tussen hoofstuk 1 en hoofstuk 2 van die Jakobusbrief nie. Wel erken hy dat Jakobus in hoofstuk 2 die 
lesers se geloof waaroor in die vorige hoofstuk gehandel is, gaan toets aan die norm wat hulle stel in die beoordeling van die mense in die kerk (1990:112). Op grond van hierdie stelling lê dit meer voor die hand om die verbindingsmotief tusssen hoofstuk 1 en hoofstuk 2 te soek in die begrip geloof. In hoofstuk 2 begin Jakobus met 'n nuwe gedeelte. Soos dikwels in sy brief begin 'n nuwe perikoop met die aanspreekvorm "my broers" met daarby'n werkwoord in die imperatief (vgl. 1:2; 5:7). Kotzé se breedvoerige struktuurontleding (1990:115) kon dus nie 'n oplossing vir hierdie spesifieke probleem bied nie.

\subsubsection{Jakobus 4:5}

Hierdie teks kan ook beskou word as 'n crux interpretum in die brief van Jakobus. Sonder om al die probleme waarmee hierdie teks ons konfronteer op te som, is daar twee vrae wat telkens deur die eksegete weer aan die teks gevra word: waar moet die leestekens in die teks geplaas word en wat is die onderwerp van die werkwoord begeer? Is dit God of die Gees (of eventueel die menslike gees)? Die aangehaalde Skrifwoord roep ook probleme op, omdat ons nêrens in die Ou Testament so 'n woord kan vind nie, maar dit daar gelaat. Die vraag is of die struktuuranalise wat Kotzé in sy kommentaar aanbied, kan help om die regte verklaring van die teks te vind. Die eerste vraag is waar die komma in die teks geplaas moet word. Sê die Skrif met betrekking tot die jaloersheid of begeer God of die Gees (gees) met jaloersheid? In die ontleding van die kolonstruktuur wys Kotzé daarop dat kolon 13 en 14 (4:4) aan die een kant en kolon 15 en 15.1 (4:5) aan die ander kant 'n parallelle opbou vertoon. Albei pare kolons bestaan uit 'n retoriese vraag plus 'n antwoord (1990:167). Kotzé trek hieruit nie 'n verdere konklusie nie. Hy stel net dat die uitdrukking of dink julle dat die Skrif tevergeefs sê ' $n$ natuurlike aanleiding tot 'n Skrifsitaat is. Sonder motivering aanvaar hy dat God die subjek van die werkwoord begeer is, waarskynlik ook omdat God die subjek van die werkwoord woon is (1990:170). Die probleem of hier sprake is van die Heilige Gees wat God in ons laat woon en of die menslike gees bedoel is, is blykbaar vir Kotzé nie 'n probleem nie. Hy stel eenvoudig die feit dat die Skrif deurgaans veronderstel dat God die Heilige Gees in 'n mens laat woon (1990:170). Dit is jammer dat die skrywer nie probeer het om met behulp van sy uitvoerige struktuuranalise 'n antwoord te gee op die probleme waarvoor hierdie teks ons plaas nie. Wat dit betref, verdien die poging van Pretorius waardering waar hy probeer het om na sorgvuldige analise 'n standpunt te stel (Pretorius, 1988a:656-659), hoewel erken moet word dat Pretorius se konklusie nie oortuigend is nie. Ondanks gebrek aan duidelike motivering klink Kotzé se verklaring meer aanvaarbaar. Deur die jongste deeglike navorsing van De Vries (1991:109) word Kotzé se konklusie as korrek bevestig. 


\section{OORWAARDERING VAN STRUKTUURONTLEDING}

'n Paar mooi voorbeelde waar struktuuranalise werklik 'n bydrae lewer tot die beter verstaan van 'n teks is Kotzé se eksegese van die uiters moeilike Jakobus 1:19-27 (1990:99-108), Jakobus 3:13 (1990:154-155) en Jakobus 5:13-18 (1990:203-208). Dit vergoed egter nie vir die feit dat die perikoop-en kolonstruktuur nie meermale in die kommentaar geïntegreer is nie. Daarom sou dit beter gewees het as net gedeeltes waar struktuuranalise diensbaar is aan die regte verklaring van die teks dit in 'n kommentaar opgeneem word. Die groot sorgvuldigheid waarmee Kotzé die analise van al die perikope en kolons van die Jakobusbrief gedoen het, verdien alle lof. Hy openbaar daarmee 'n groot gevoel vir taal, taalstruktuur en 'n groot vaardigheid in stylanalise.

Soms gaan Kotzé egter werklik te ver as hy van die struktuur van 'n teks verwag wat die teks self moet doen. Soos ons reeds gesien het, skryf hy dat Jakobus met die struktuur van Skrifbewys die integrale eenheid tussen geloof en werke wil aantoon (1990:131). Dit is egter die Skrifbewys self en nie sy struktuur nie wat dit doen. Ook laat hy soms die boodskap van 'n perikoop mede uit die struktuurontleding kom in plaas vanuit die kommentaar $(1990: 95,131)$ - dit wys op 'n oorwaardering van struktuurontleding. Wel Inoet dit Kotzé toegegee word dat Jakobus deur middel van struktuur en styl bepaalde sake vir sy lesers wil beklemtoon (1990:95).

\section{KOMMENTAAR}

\subsection{Dit wat in die Jakobusbrief verswyg word}

In sy artikel "Das semantische Netz des Jakobusbriefes" wys Frankemölle op "die eventuel verzweigte Vorgeschichte eines Textes" (1990:161). In verband met die verstaan van die brief van Jakobus is dit baie belangrik om ook aandag te gee aan dit wat nie in die brief van Jakobus geskryf staan nie. Kotzé het in sy kommentaar op hierdie saak ook uitvoerig ingegaan. Dit het verskillende kommentatore opgeval dat Jakobus nêrens in sy brief verwys na die groot heilsgebeure van kruis en opstanding nie. Volgens Mitton (1966:8) veronderstel Jakobus by sy lesers soveel kennis oor die versoeningswerk van Christus dat die doel met die brief nie aanleiding en ruimte bied om 'n breedvoerige, didaktiese uiteensetting oor die basiese Christelike waarhede te gee nie. Morris (1979:309) wys in dieselfde rigting. Jakobus stel die Here Jesus voor as die verhoogde Heer aan die regterhand van God (2:1); tereg sê Kotzé dat dit kruis, opstanding en hemelvaart impliseer. In verband hiermee skryf hy in sy kommentaar: 
Trouens, die Paasgebeure vorm die groot voorveronderstelling vir die inhoud van die brief. Die betekenis daarvan word as vanselfsprekende kennis by die lesers aanvaar" (1990:48). Hierdie afleiding is uit teologiese gesigspunt geheel aanvaarbaar, maar dit is wel 'n gegewe wat van buite af na die teks gedra en selfs in die teks ingedra word. Die eerste Christelike lesers het nie in 'n tradisielose ruimte geleef nie. Calvyn het reeds opgemerk dat die eerste lesers van die brief van Jakobus geen lering nodig gehad het nie maar vermaning (1973:223). Wat in die vroeë kerk geleer is, was vir hulle dus algemene kennis. Hulle weet van die credenda, die dinge wat hulle moet glo en nou kom Jakobus en hy wys hulle op die agenda, die dinge wat hulle moet doen. Kotze gaan egter verder en hy gebruik hierdie versweë voorveronderstelling as 'n hulpmiddel by sy eksegese vir die verstaan van die inhoud van die brief van Jakobus.

\section{Die rol van voorveronderstellings by eksegese}

By sy verklaring van Jakobus 1:1 oordeel Kotzé dat Jakobus sy roeping volledig op die verlossingswerk van die Here Jesus Christus baseer. Christus se leer, sy sterwe en opstanding gee karakter en betekenis aan die bediening van Jakobus (1990:67). Kotzé is wel diep deurdronge van die feit dat hier probleme lê, want hy skryf dat die hermeneutiek worstel met die vraagstuk van die rol wat voorveronderstellings speel in die omgang met die teks en die Woord. Dit gaan dan vir Kotzé veral om voorveronderstellings by eksegeet, prediker en gemeente. Hy skryf: "Die opvoedkundige, sosiale, kulturele, ideologiese en ekonomiese verwysingsraamwerk van die eksegeet en bedienaar van die Woord asook die verwysingsraamwerk van die gemeente aan wie die Woord verkondig word, wil hulle eie woord meespreek in die verkondiging van die Woord" (1990:67). Maar hierdie uitspraak geld ook van die skrywer (Kotzé) en die eerste lesers van 'n Nuwe-Testamentiese dokument. Kotzé oordeel dat hier op die pad gevare opdoem, en daarom wil hy korreksies aanbring deur middel van 'n gesindheid van onvoorwaardelike onderwerping van voorveronderstellings aan die spreke van die goddelike Woord (1990:67). Ons kan hiermee hartlik saamstem, maar dan bly dit nog 'n vraag of dit uit hermeneutiese oogpunt legitiem is om van voorveronderstellings gebruik te maak. Kotzé doen dit met soveel oortuiging dat hy selfs die sentrale tema van die brief van Jakobus formuleer met behulp van die groot versweë voorveronderstelling van Christus se kruis en opstanding. Hy beskou die sentrale tema van die brief as "... die oproep van die skrywer dat die verlossingswerk van God sy volkome doel sal bereik in die lewe van die gelowigen (1990:80). Eksegese het hier teologiese eksegese geword. 'n Gereformeerde eksegeet kan ook nie anders met die Bybel werk nie, maar 'n uitgewerkte struktuuranalise van die teks gaan op hierdie manier tog wel iets van sy 
relevansie verloor. Dit beteken hoegenaamd nie dat struktuuranalise nie meer belangrik is nie, maar daar vind 'n gesonde relativering plaas en 'n heilsame korreksie op 'n oorwaardering van struktuurontleding. Op hierdie manier is Kotzé getrou aan die belangrike reformatoriese hermeneutiese reël Sacra Scriptura sui ipsius interpres, maar dit is juis hierdie hermeneutiese reël wat vandag bevraagteken word. Deist (1986:105) is oortuig dat hierdie reël van die rabbyne afkomstig is. Die groot Reformatoriese teoloë het hulle eksegetiese opleiding by Jode gehad en so het die Joodse eksegetiese praktyk daarmee ook in die Hervormde wêreld ingang gevind. Ook Botha (1989:38) waarsku dat 'n mens op woordvlak uiters versigtig moet wees om die sogenoemde 'Skrif-met-Skrif-vergelyking' as eksegetiese prosedure te gebruik. Die vraag moet gevra word of Kotzé op hierdie wyse nie wegbeweeg het van die eintlike doelstelling van hierdie kommentaar, naamlik om via struktuurontleding en uitleg op grond van die struktuurontleding by die boodskap uit te kom nie. Die teologiese natuur van die skrywer blyk dan tog sterker te wees as die hermeneutiese leer van die beplanners van hierdie kommentarereeks.

\subsection{Aktualiteit van die boodskap van Jakobus}

Die krag van hierdie kommentaar en sy groot waarde lê inderdaad in sy boodskap. Die kommentator het uitnemend daarin geslaag om die aktualiteit van die boodskap van Jakobus duidelik te maak. Daar is te veel voorbeelde om almal te noem. Daarom word net op die volgende gewys:

8.3.1 $\mathrm{Na}$ ' $n$ uitvoerige eksegese van Jakobus se siening van 'n oordeel oor ander mense volgens wêreldse maatstawwe (perikoop 6), die gevaar van materialisme (perikoop 9 en 10), selfvertroue en liefde vir die wêreld (perikoop 10), wys die skrywer daarop dat die kerk vandag tot besinning geroep moet word omdat hy in hierdie wêreld in vreemdelingskap verkeer. Die kondisioneringsmag van die tegnologie, tegnokrasie, pragmatisme en materialisme het 'n bedwelmende invloed waarin die kerk hom nie tuis mag voel nie, anders is dit besig om sy 'andersheid' in te boet (1990:68).

8.3.2 Die skrywer gee 'n besonder breë en boeiende eksegese van die verhouding rykes teenoor armes in die Jakobusbrief (1990:49-51; 80-83; 184-190). Hy toon aan dat daar voor die verwoesting van Jerusalem in 70 n.C. en in 'n mate reeds voor die Joodse oorlog van 66 n.C. in die Palestynse gemeenskap 'n soort twee-klasse-maatskappy was: die ryk grondbesitters en handelaars en die verarmdes.

8:3.3 Kotzé (1990:125) toon op 'n oortuigende manier in sy kommentaar aan dat diskriminasie as sonde veroordeel moet word. Hoewel diskriminasie vandag wêreld- 
wyd met intense emosie veroordeel word, toon die skrywer aan dat daar by die veroordeling van diskriminasie tog vreemde motiewe 'n rol kan speel. Vanuit sy eksegese van die Jakobusbrief wys Kotzé daarop dat die kinders van die koninkryk 'n onontwykbare verantwoordelikheid het om te profeteer teen diskriminasie maar dat dit gedoen moet word vanuit suiwer Christelike motiewe.

8.3.4 Kotze (1990:109) het kennis geneem dat daar in Suid-Afrika al meer stemme opgaan wat roep om herlewing. Hy het hierdie stemme getoets aan die brief van Jakobus en tot die konklusie gekom dat baie van hierdie stemme moraliserend klink en daarom kerugmaties gevaarlik is (1990:109). Kotzé is oortuig dat gelowiges uit 'n gereformeerde Protestantse tradisie op grond van hulle Protestantse erfenis die regverdiging op grond van die genade eensydig beklemtoon (1990:108). In die praktyk kom dit neer op 'n skeiding tussen twee aspekte van die Christelike eksistensie wat wel onderskei kan word maar nie geskei nie - die indikatief en die imperatief. Op grond van sy eksegese van Jakobus 1:19-17 maak die skrywer die skitterende stelling: "Die toets vir die man wat die woord hoor maar dit nie doen nie, is in die eerste plek 'n toets van oorsprong en geboorte, en in die tweede plek 'n toets na gemeenskap."

8.3.5 $\mathrm{Na}$ aanleiding van Jakobus se opmerkings aor die sweerverbod (perikoop 15) wys Kotzé op die groot ooreenkoms wat die eedverbod by Jakobus het met die Jesuswoorde van Matteus 5:34-37. Hy toon aan dat die Matteus-weergawe meer uitgebreid is as dié by Jakobus. Dit taal in Matteus met die preposisie $e n+$ die datief is tipies die Koine van die Nuwe Testament. Jakobus beweeg met sy formulering nader aan die klassieke Grieks. Wanneer Jakobus van die Matteus-tradisie gebruik maak, geskied dit volgens Kotzé gewoonlik in die vorm van saakooreenkoms eerder as woordooreenkoms. Dit laat die vermoede ontstaan dat Jakobus geskryf is voordat die evangelies hulle skriftelike beslag gekry het (1990:200). Kotzé gaan dan met die resultate van sy eksegese na die praktyk van die lewe van vandag wanneer hy skrywe dat die maatstaf vir' $n$ groot deel van ons gemeenskapslewe, veral die polities- en ideologies-georiënteerde lewe, nie meer die waarheid is nie, maar dit wat voordelig is. Verkiesings word gevoer met wanvoorstellings. Dit skep 'n klimaat van algemeen aanvaarde praktyk waardeur die gelowige maklik gekondisioneer kan word aan 'n lewe waarin daar nie meer ' $n$ hoë premie op die waarheid geplaas word nie. Onder sulke omstandighede moet ons volgens Kotzé profeties saam met Jakobus getuig dat so iets nie te rym is met die geloof in ons Here Jesus Christus, die Here van die heerlikheid nie (1990:201).

8.3.6 Waar geloofsgehoorsaamheid so sterk in die brief van Jakobus beklemtoon word, moet dit besonder waardeer word dat Kotzé in sy kommentaar so duidelik daarop wys 
dat die Woord in sy imperatiewe vorm, die logos as nomos, die woord as wet gehoorsaamheid vra, maar dit tegelyk ook bewerk. Vir Jakobus bestaan daar nie 'n skeiding tussen die indikatief en die imperatief nie - dit funksioneer as eenheid (1990:106). "Dat het evangelie de wet in zich draagt, wil dus zeggen, dat God geeft wat Hij eischt en dat Hij eischt wat Hij geeft" (Woelderink, 1974:100).

8.3.7 Volgens Kotze is die brief van Jakobus daarop toegespits om die afgedwaalde tot bekering te roep. $\mathrm{Na}$ aanleiding van die eksegese van perikoop 17 wys Kotzé op die aktualiteit van die bekeringsboodskap van die kerk. Kursusse en opleiding in verband met die toerusting van die gelowiges vir hulle taak in die wêreld ag Kotzé noodsaaklik, mits die gevare daaraan verbonde vermy word. Hy pleit egter sterk vir natuurlikheid en spontaneiteit in kommunikasie wat maklik opgeoffer kan word aan reëls en voorgeskrewe gedragskodes. Daarom sluit hy sy kommentaar af met die opmerklike sin: "Die adekwate 'opleiding' skyn te wees 'n opregte geloof in die Here Jesus Christus en 'n volharding in die leer. Daarmee het lidmate van die vroeë kerk hulle getuienis gelewer en die Here het hulle getuienis gebruik tot bloei van die Kerk" (1990:211).

\section{SLOTKONKLUSIE}

Hoewel daar dus vraagtekens geplaas kan word rakende die wenslikheid van so 'n uitgebreide struktuurontleding in 'n kommentaar, is die uitleg en boodskap wat in hierdie boek aangebied word van so 'n hoë gehalte dat dit beslis die moeite en die geld werd is om hierdie boek aan te skaf.

Die oogmerk van die reeks om die uitleg van die Bybel diensbaar te maak aan die prediking van die kerk is met hierdie kommentaar sekerlik bereik.

\section{BIBLIOGRAFIE}

ADAMSON, J.B. 1954. An inductive approach to the Epistle of James: Material for a fresh study. Cambridge : Cambridge University Press.

ADAMSON, J.B. 1976. The Epistle of James. Grand Rapids : Eerdmans.

ADAMSON, J.B. 1989. James. The man and his message. Grand Rapids : Eerdmans.

BOTHA, J. 1989. Praktiese riglyne vir die gebruik van die Louw \& Nida-woordeboek. In die Skriflig, (23):24-39.

CALVYN, J. 1973. Uitlegging van de Algemene Zendbrieven. (Vert. A.M. Donner). Goudriaan : De Groot.

COETZEE, J.C. 1988. Gedagtestruktuurontleding en die eksegese van die Heilige Skrifte. Koninkryk, Gees en Woord. Huldigingsbundel aangebied aan prof. dr. Lambertus Floor (In Coetzee, J.C. red. Pretoria : NG Kerkbockhandel p. 19-37.) 
DAVIDS, P.H. 1982. The Epistle of James: A commentary on the Greek tex. Exeter : The Paternoster Press.

DEIST, F.E. 1986. Kan ons die Bybel dan nog glo? Onderweg na 'n Gereformeerde Skrifbeskouing. Pretoria : Van Schaik.

DE VRIES, E. 1991. De brief van Jakobus. Dispositie en theologie. Kampen : Kok.

DU PLESSIS, M.J. 1989. Die gemeenskap van die heiliges in die inleidings van Filemon, Filippense en Galasiêrs: 'n ondersoek na die funksie van die struktuurmerkers in die inleidings van die briewe. Potchefstroom : PU vir CHO.

FLOOR, L. 1991. Wet en evangelie in die brief van Jakobus. (In Van Genderen, J. red. Ten dienste van het Woord: opstellen aangeboden aan prof. dr. W.H. Velema. Kampen : Kok p. 93-108.)

FRANKEMŌLLE, H. 1990. Das semantische Netz des Jakobusbriefes. Zur Einheit eines umstrittenen Briefe. Biblische Zeitschrift, 34 (2):161-197.

GREIJDANUS, S. 1949. Bizondere Canoniek van de boeken van het Nieuwe Testament. Deel II Kampen : Kok.

KITTEL, G. 1942. Der geschichtliche Ort des Jakobusbriefes. Zeitschrift für die Neutestamentliche Wissenschaft, (41):71-105.

KOTZE, P.P.A. 1990. Die brief van Jakobus. (In Combrink, H.J.B. red. Kommentaar op die Nuwe Testament. Struktuur - Uitleg - Boodskap. Kaapstad : Lux Verbi.)

LAWS, S. 1980. A commentary on the Epistle of James. London : Adam \& Charles Black.

LOUW, J.P. \& NIDA, E.A. 1988. Greek-English Lexicon of the New Testament based on semantic domains. New York : UBS.

MITTON, C.L. 1966. The Epistle of James. Grand Rapids : Eerdmans.

MORRIS, L. 1979. The cross in the New Testament. Exeter : Paternoster Press.

MUSSNER, F. 1967. Der Jakobusbricf. Freiburg : Herder.

PERDUE, L.G. 1981. Paranesis and the Epistle of James. Zeitschrift für die Neutestamentliche Wissenschaft und die Kunde der alleren Kinche, 72: 241-256.

POPKES, W. 1986. Adressaten, Situation und Form des Jakobusbriefes. Stuttgart: Verlag Katholisches Bibelwerk.

PRETORIUS, E.A.C. 1988a. Drie nuwe verklaringsopsies in die Jakobusbrief (Jk 2:1; 4:5; 5:6) Hervormde Teologiese Studies, 44(3):650-664.

PRETORIUS, E.A.C. 1988. Die Brief van Jakobus. Kaapstad : NG Kerk Uitgewers.

ROSS, A. 1972. The Epistles of James and John. Grand Rapids : Eerdmans.

VAN BRUGGEN, J. 1984. Ambten in de apostolische Kerk. Een exegetisch mozaiek. Kampen : Kok.

VAN DER WALT, S.J. 1984. Die plek van Christus in die etiese uitsprake van die Jakobusbrief en die betekenis daarvan vir die teologiese etiek. Potchefstroom : PU vir CHO.

VORSTER, W.S. 1987. Diskriminasie en die vroeë kerk: gedagtes oor partydigheid in Jakobus 2:1-13. (In Breytenbach, C. red. Eenheid en konflik. Eerste beslissinge in die geskiedenis van die Christendom. Pretoria : NG Kerkboekhandel p. 134-149.)

WOELDERINK, J.G. 1974. Verbond en bevinding. Amsterdam : Bolland. 